\title{
Oppiva laatuorganisaatio
}

\author{
Urpo Sarala - Anita Sarala: Oppiva organisaatio -oppimisen, laadun ja tuottavuuden \\ yhdistäminen. Helsingin yliopiston Lahden tutkimus- ja koulutuskeskus. Tammer-paino, \\ Tampere 1996. Nidottu, 214 sivua.
}

Urpo ja Anita Saralan kirja tuli markkinoille talvella ja vastaa osaltaan tarpeeseen, jota tämäntyyppiselle kirjalle on: ensimmäinen, tuhannen kappaleen painos on jo loppuunmyyty ja toinen painos on otettu.

Oppivan organisaation käsite on monilta osilta keskustelunalainen. On erilaisia käsityksiä siitä, mikä on "oppiva organisaatio".

Selvää lienee, että oppiva organisaatio on artefakti; eihän organisaatio sellaisenaan mitään opi. Organisaatio koostuu ihmisistä, jotka oppivat mikäli ovat oppiakseen. Yksilöiden oppiminen saattaa koitua organisaation osaamiseksi, ja tässä on mielestäni oppivan organisaation problematiikan ydinkohta. Miten yksilöiden osaaminen ulotetaan organisaation hyödyksi? Tapahtuuko siirtymä yksilön osaamisesta organisaation osaamiseksi tiimeissä vai jossain muualla? Esimerkiksi nämä kysymykset ja monet muutkin ovat keskustelunalaisia. Siten ei voida olettaa, että käsitteen syvimmästä olemuksesta vallitsisi yksimielisyys -siihen ei liene järkevää pyrkiäkään.

Oppivan organisaation idea ei ole mikään uusi keksintö, sillä organisaatioiden kehittämistä on harrastettu niin kauan kuin organisaatioita on ollut olemassa. Esimerkiksi Argyris ja Schön (1978) tarkastelivat oppimista organisaatiossa. Vieläkin aiemmista kirjoittajista voidaan mainita Cyert ja March (1963), joiden työt pureutuvat kyberneettisiin malleihin.

\section{Vertautuminen sengeläiseen ajatteluun}

Saraloiden kirja avaa oppivaan organisaatioon laatujohtamisen ideoista lähtevän näkökulman. Kirjoittajien yritys yhdistää laatuajattelun ydinkohtia ja oppivan organisaation tiimoilta viime vuosina käytyä keskustelua on mielenkiintoinen, tuloksena hahmotelma oppivasta laatuorganisaatiosta.

Laatujohtaminen lähtökohtana ja eteneminen sen mukaisesti organisaatiossa tapahtuvaa oppimista tarkasteltaessa aiheuttaa mielestäni selkeän eron tunnetun kirjoittajan Peter Sengen näkemyksiin. Sengen (1990, 1995) teoksissa lähtökohtana on vahva systeemiajattelu. Sengen viisi periaatetta, systeemiajattelu (systems thinking), itsehallinta (personal mastery), sisäiset toimintamallit (mental models), jaettu visio (shared vision) ja tiimioppiminen (team leaming), mainitaan kyllä käsillä olevassa kirjassa sivuilla 60-62. Muuten Sengen ajatuksiin Saralat eivät juurikaan tukeudu. Sengen sivuuttaminen Saraloiden tuoreessa kirjassa ei sinänsä ole ihme, kun hänelle ei panna kovin paljon painoa kirjoittajien aiemmassakaan tuotannossa

\section{Burgoynelainen monien tekijöiden summa}

Henkiseltä otteeltaan sijoittaisin Saraloiden kirjan Jobn Burgoynen (1994 Towards the Learning Conip Concepts and Practice -teoksen lähelle. Siinä useat kirjoittajat esittävät osa-alueita, joista kaikista yhdessä voidaan ajatella op van organisaation kaltaisen a paraatin syntyvän. jokaisen o alueen käsittely tuo oman kulman oppivan organisaatio problematiikkaan. Vaikka teema näin käsitellen hieman hajoaakin, lukijalle tulee selväksi, että oppivan organisaation konsepti ei ole jokin "Lopullinen ratkaisu», Pikemminkin se on prosessi, jossa organisaation vahvuusalueet pystytään tunnistamaan ja kombinoimaan kilpailukykyä tuottavalla tavalla. Prabalad ja Hamel (1990) tuovat keskusteluun ydinosaamiskonseption, ja usein organisaatioiden kehittämisessä lieneekin kyse ydinosaamisen tunnistamisesta, vahvistamisesta ja synergian tietoisesta luomisesta.

Edellä mainitsemani pätee myös Saraloiden kirjaan, jossa oppivan laatuorganisaation kehittämisalueiksi nimetään viisi: tosiasioiden tunnistaminen ja oman tulevaisuuden juonti; työkulttuurin ja ilmapiirin kehittäminen; laadun, tuottavuuden ja prosessien kehittäminen; oppimisen edistäminen; kehittämistoiminnan ja verkostojen juonti. Näitä kehittämisalueita läpikäydään siten, että tuottavuuden, laadun ja prosessien kehittämiseen liitetään oppimisnäkökulma.

\section{Oppimisen edistäminen ja esteet}

Oppimisen edistäminen on saanut osakseen kolmekymmentä sivua, joilla sivuilla painotetaan oppimisnäkökulman tietoista mukaanottamista organisaatiota kehitettäessä. Kasvatustieteilijälle 
ennestään tuttu on kokemusperäisen oppimisen sykli, joka esitetään Kölbin (1984) kehän mukaan. Tässä kehässä edetään välittömästä kokemuksesta reflektiiviseen havainnointiin, siitä abstraktiin käsitteellistämiseen ja aktiiviseen kokeilevaan toimintaan.

Kim (1993) täydentää Kolbiri ajatusta organisaation oppimisen suuntaan esittämällä, että yksilöllinen ja organisaation oppiminen voidaan erottaa. Hän väittää, että kun organisaatio on suurempi kuin muutaman henkilön käsittävä, ero yksilöllisen ja organisaation oppimisen välillä kasvaa. Kim näkee tärkeimpänä. Organisaation oppimista edistävänä tekijänä jaetut mentaaliset mallit, joista Sengekin puhuu: Kun yksilö oppii, hän tarkistaa mentaalisia mallejaan. Nämä muutokset heijastuvat organisaation mentaalisiin malleihin, joiksi voidaan ymmärtää esimerkiksi organisaatiokulttuuri ja -ilmasto.

Oppimisen esteiden tunnistamisesta olisin itse kaivannut enemmän tekstiä kuin kirjassa esitetyn suppean listan (s. 154). Oppimisen esteiden kartoitus on nähdäkseni tärkeää, sillä näitä esteitä on löydettävissä yksilön

tasolla (kyvyttömyys/haluttomuus oppia), työryhmän tasolla (toimimattomat tiimit), ja organisaation tasolla (organisaation puolustusmekanismit uusia vaikutteita kohtaan).

\section{Taylorismista}

Käsillä oleva kirja on jaettu kahteen pääosaan, joista ensimmäinen, "Johdon kyvykkyydestä kohti koko organisaation kehittämistä", valottaa aiemmin pinnalla olleita organisaatioiden kehittämiskäytäntöjä. Katsaus on tarpeellinen, sillä se antaa perspektiiviä erilaisten OD-strategioiden tilaukselle. Liikkeelle lähdetään tayloristisesta organisaatiomallista, joka oli massatuotannon aikakaudella vuosisadan alkupuolella keskeinen hyvinvoinnin ja taloudellisen kasvun moottori. Taylorini hyvin lukeneena en malta olla halkomatta hiuksia, sillä Saraloiden kirjassa Taylorin ajatuksiin viitataan vuodelle 1914, jolloin tieteellisestä liikkeenjohdosta ilmestyi suomennos; Taylorin The principles of Scientific Management puolestaan painettiin jo vuonna 1911, ja vuonna 1912 Taylor joutui puolustamaan vahvaa vastarintaa herättäneitä oppejaan edustajainhuoneen komitean kuulustelussa. (Taylor 1911, Taylor 1912).

Itse kunkin sopinee miettiä oppivan organisaation konseptista puhuttaessa, minkälainen suhde taylorismissa ja oppivan organisaation ajatuksessa on. Työtehtävät ovat muuttuneet, käsityön ja ruumiillisen työn osuus tuotannossa on laskenut ja henkisen työn merkitys on kasvanut. jopa "raskailla" teollisuuden aloilla, kuten paperiteollisuudessa henkisen kompetenssin merkitys on nykyisin keskeinen(Zuboff 1988).

Henkisen työn tuottavuutta on paljon vaikeampi mitata kuin Taylorin aikoina määräävänä vallinnutta ruumiillista työtä. Yritys on kuitenkin kova, sillä perinteisesti (funktionaalisesti tai tayloristisesti) johdetussa organisaatiossa tulosten mittaaminen on keskeistä samoin kuin työtehtävien kontrollointi. Pyritäänkö oppivan organisaation konseptilla vastaamaan muuttuneeseen tehokkuuden ja kontrollin vaatimukseen? Kirjoittajien suhtautumista organisaation kehittämisstrategiohin kuvaa lainaus sivulta 16 "Ihmiskeskeisyyden lisäys ei pääpainotteisesti ole minkään filosofian tai aatesuuntauksen seurausta, kuten kirjallisuudessa usein esitetään. Sen keskeisenä perussyynä voidaan pitää halua lisätä toiminnan tuottavuutta." Mielestäni suhtautumistapa kuvaa realiteettien tuntemusta, ja tosiasioiden tunnustaminen on viisauden alku, kuten jo Paasikivi totesi.

\section{Kaksi kehittämishanketta}

Krirjan viimeiset parikymmentä sivua on omistettu kahden kehittämishankkeen kuvailulle (Helsingin kaupungin rakennusvirasto sekä Datex Oy) sekä selosteelle käynnissä olevasta oppivasta laatuorganisaatiosta oppimiskeskusten kehittämismallina. Hankekuvaukset puolustavat paikkaansa, sillä runsaan oppivan organisaation ympärillä käydään kyllä paljon keskustelua, mutta tiedossani on vain vähän konkreettisia kehittämishankkeita.

Yleisesti ottaen kirja sopii mielestäni parhaiten käsikirjatyyppiseksi tietolähteeksi, joskin laaja näkökulma tuo väkisinkin tekstiin paikoittain hajanaisuuden tuntua. Kirja olisi myös astetta käyttökelpoisempi, mikäli siinä olisi aakkosellinen hakemisto -tämän puuttuminen haittaa asioiden löytymistä ja puute olisi ollut suhteellisen vaivattomasti korjattavissa nykyisten tekstinkäsittelyohjelmien aikakaudella. Vastapainoksi moitteille voin todeta, että kirjaa varten käytetty lähdeaineisto on runsas ja ennen kaikkea tuoretta. Käytännönläheisyys on myös mielestäni positiivista, etenkin jos kirjaa ajattelee aikuiskouluttajan työvälineenä. 
Argyris, Cbris \& Schön, David 1978. Organizational learning. A theory of action perspective. Addison-Wesley. Reading, Mass.

Burgoyne, John 1994. Towards the Learning Company: Concepts and Practice. McGrau,,Hill International. Great Brittain.

Kim, Daniel 1993. The Link between Individual and Organizational Learning. Sloan Management Review, Fall 1993, vol. 35, nr 1.

Kolb, David 1984. Experiential Learning Experience as the Source ofLearning and Development

Prabalad C \& Hamel Gary 1990. The Core Competence of the Corporation. Harward Business Review, Mayjune, pp. 5-16

Senge, Peter 1990. The Fifth Discipline. Doubleday-Currency. New York.

Serge, Peter 1994. The Fifth Discipline Fieldbook. Doubleday-Currency. New York.

Taylor Frederick 1911. The Principles of Scientific Management Reprint of Taylors Works 1964. The Harper International Student Reprint.Jjapan.

Taylor's Testimony Before the Special House Committee 1912. Reprint of public document, Hearings Before Special Committee of the House of Repre. sentatives to Investigate the Taylor and Other Systems of Shop Management Under Authority of H. Res 90 Vol. III. PP. 1377-1508. Harper International Student Reprint japan.

Zuboff, Sosbana 1988. In the Age of the Smart Machine - the Future of Work and Power Basic Books. New York. 